\title{
Efficient Way to Use Whey as Ready to Serve (RTS) Beverage
}

\author{
Basant Bais ${ }^{1 *}$, Parma Ram Gorachiya ${ }^{2}$, Lokesh Tak ${ }^{2}$, Sanjay Singh ${ }^{2}$ and Durga Devi ${ }^{2}$ \\ ${ }^{1}$ Department of LPT, Bikaner, India \\ ${ }^{2}$ Department of Livestock Products Technology, India
}

Received: September 23, 2017; Published: October 05, 2017

*Corresponding author: Basant Bais, Professor and Head, Department of LPT, CVAS, RAJUVAS, Bikaner, Rajasthan, India,

\begin{abstract}
Whey is the largest by product of huge dairy industry and is one of the most troublesome byproduct produced. Whey based beverages with different concentrations of fruit juices and standard ingredients of Ready to Serve (RTS) beverage can be prepared. Ready to drink beverages offer the advantages of convenience and portability to today's busy consumers. Utilization of whey for the conversion into best beverage would be one of the important ways to utilize it. Nutritive value of whey may be increased by the addition of some simple ingredients. Whey proteins are often the preferred source for ready-to-drink protein beverages because of their excellent nutritional qualities, bland flavor, ease of digestibility, and unique functionality in beverage systems.
\end{abstract}

Abbreviations: RTS: Ready to Serve

\section{Introduction}

Utilization of whey produced during the manufactures of cheese, paneer, channa and shrikhand has been of great concern. In India, it is estimated that about 100 million $\mathrm{kg}$ of whey is annually derived as a byproduct which may cause substantial loss of about 70,000 tonnes of nutritious whey solids [1]. Whey, a valuable dairy by product contains half of the milk solids and is a rich source of lactose, water soluble vitamins, minerals, and immunologically active proteins [2]. It contains about 50-55\% total milk solids, 70\% of milk sugar, $20 \%$ of milk proteins and $70-90 \%$ of minerals and almost all water soluble vitamins especially vitamin B complex and vitamin C [3]. Whey proteins consist of lactoferrin, lactoperoxidase, $\beta$ lactoglobulin, $\alpha$-lactalbumin, bovine serum albumin, thermostable fractions of proteose peptones, immunoglobulins and bioactive peptides. Presence of essential amino acids such as lysine, cysteine, methionine and cystin imparts anticarcinogenic properties to these proteins [4].

However, large quantities of whey are drained off as waste. There is an increased awareness all over the world on the potential for utilization of whey, primarily because of stringent pollution prevention regulations and secondly on salvaging the unique components of whey nutrients to improve the functional quality of formulated foods [5]. Whey proteins have unique nutritional and functional properties which can be explored to deliver high protein products to consumers. Dairy proteins are generally having a neutral-pH, therefore they can be used in manufacturing of beverages which are having different nutritional and functional attributes Development of RTD drinks relies on the fact that caseins are very heat stable at neutral $\mathrm{pH}$. Whey proteins are not as heat stable at neutral $\mathrm{pH}$, which is whey caseins or milk proteins appear much higher on the typical ingredient legend. Whey protein as a ingredient is generally used in manufacturing of products like; sports drinks, beverages, smoothies, meal replacements etc. Whey proteins have a fresh, neutral taste which can be used to prepare beverages by utilizing different fruits and vegetables.

Whey proteins are present in small quantity but have a high protein efficiency ratio (3.6), net protein utilization (95), biological value (104) and as compared to all other protein sources available they are next to egg protein in terms of nutritive value. Whey proteins is a source of $\alpha$-lactalbumin, $\beta$-lactoglobulin, bovine serum albumin, caseinomacropeptides, immunoglobulins, lactoferrin, lysozyme which are often associated with health benefits, such as enhanced immunity, anticancer properties, ant adhesive effect against pathogenic properties, as well as antiviral, antimicrobial (iron binding properties) and antihypertensive properties. The conversion of whey into beverages through fermentation or without fermentation is one of the most attractive avenues for the utilization of whey for human consumption. In terms of functionality, whey protein enhances protein content of beverage while improving its quality.

\section{Functional Properties of Whey and Whey Derivatives}

Whey and whey derived products besides being a nutritional ingredient in various foods can also be used as functional ingredient supplying flavor, texture, colour and certain aeration properties in variety of foods. Whey proteins possess very good functional properties, such as solubility, foaming, emulsifying, 
gelling and water binding. The solubility of whey proteins is high at all $\mathrm{pH}$ values when compared to other proteins like caseins and soy protein which are highly $\mathrm{pH}$ dependent. Whey protein from gels and bind considerable amounts of water when heated and this were found important in baked foods, meat products and processed foods. Whipping and foaming properties of whey proteins was excellent and they were found next only to egg white, whey proteins were also found to be very good emulsifying agents.

\section{Whey Beverages Based On Fruit Juices}

Mixtures of fruit juices and unprocessed or deproteinated whey or UF permeates are the most common types of whey drinks to be manufactured. These products usually fulfill a role similar to typical fruit juices, including breakfast type beverage, healthful fruit juice snack-type drink, or drinks with a healthful image as a source of vitamins. The main two basic ingredients are typically liquid whey and liquid fruit juice or, more likely, fruit juice concentrate. The flavors used in these beverages most often include citrus fruits (mainly orange, followed by lemon, rarely grapefruit), as well as mango, passion fruit, pear, apple, strawberry, raspberry or fruit juice combinations with exotic descriptive terms ('tropic mix', 'multi-fruit', 'fruit nectar', etc.) since they have proved to be very efficient in covering up the undesirable odor of cooked milk and salty-sour flavor of fresh whey [6]. The additions of berries which are known as a good source of iron and antioxidants have proved to be very useful. Best example is a whey drink flavored by addition of strawberry concentrate and fortified with ferrous bisglycinate. Long-term consumption of this drink had an impact on reduction in the prevalence of anemia in children and adolescents [7].

\section{Conclusion}

For a beverage to be accepted by the modern consumers, it has to satisfy at least some of the main determinants of success- desirable sensory quality, thirst-quenching effectiveness, favorable price and positive 'health image'. Consumer features like convenience, practicability, flavor, nutritional value, variants are generally affecting the market size of the functional drinks. As far as milk is concerned, it is now steadily becoming a functional drink in its various forms like drinkable yoghurt, flavored milk and others and a vital role will be played by whey based drinks. Whey drinks with added carbohydrates and increased level of salts can be used for formulating sports drinks which will be having different function like recovery of muscle and muscle cramps, increase in lean weight, overcoming the adenine nucleotides depletion, acting as a neuro-stimulant, Glycogen depletion and others. Whey and whey based products can be used to formulate different beverages with multiple application and functionalities.

\section{References}

1. Parekh JV (2006) Emerging new technologies in the dairy industry in India. FNB News, India.

2. Durham RJ, Hourigan JA, Sleigh RW, Jhonsen RL (1997) Whey fraction: wheying up consequences. Food Aust 49: 460-465.

3. Sinha R, Radha C, Prakash J, Kaul P (2007) Whey protein hydrolysates: functional properties, nutritional quality and utilization in beverage formulation. Food Chem 101: 1484-1491.

4. Jelicic I, Bozanic R, Tratnik L (2008) Whey based beverages-new generations of dairy products. Mljekarstvo 58: 257-274.

5. Jayaprakasha HM, Brueckner H (1999) Whey protein concentrate; a potential ingredient for food industry. J Food Sci Technol 36: 189-204.

6. Duric M, Caric M, Milanovic S, Tekic M, Panic M (2004) Development of whey based beverages. European Food Research and Technology 219(4): 321-328.

7. Miglioranza LSH, Matsuo T, Caballero Cordoba GM, Dichi JB, Cyrino ES, et al. (2003) Effect of long-term fortification of whey drink with ferrous bisglycinate on anemia prevalence in children and adolescents from deprived areas in Londrina, Parana, Brazil. Nutrition 19(5): 419-421.

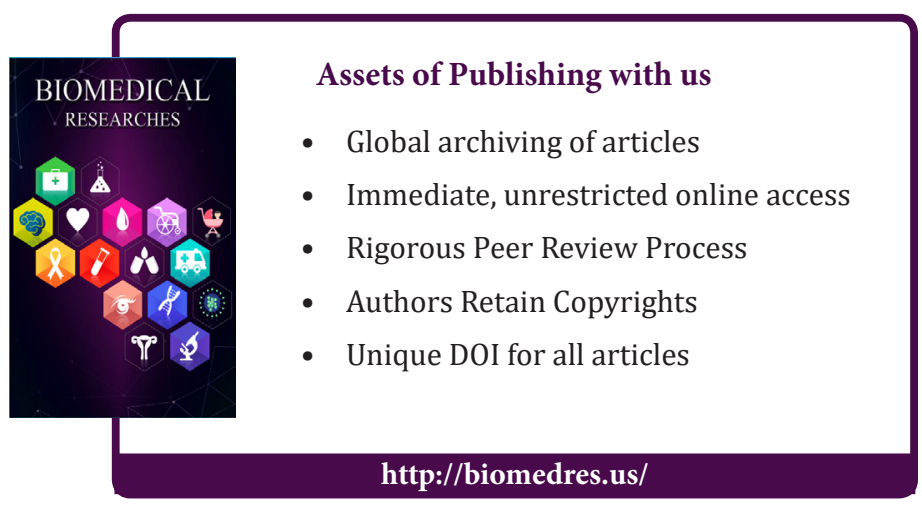

